\title{
Research on Present Conditions and Improvement Strategy of College English Listening and Speaking Teaching
}

\author{
Weiwei Feng \\ Xi'an University, School of Foreign Studies, 710065
}

\begin{abstract}
Keywords: College English; Listening and Speaking Teaching; Present Conditions; Improvement Strategy
\end{abstract}

\begin{abstract}
As the development trend of economic globalization is becoming more and more intense, China must also follow the trend of the times, actively participate in economic globalization, and frequently exchange with other countries. English has become a universal language today. To enhance active communication and trade contact with other countries, the Chinese shall master proficient English skills. Some non-English-speaking countries are gradually engaged in the trend of English learning, the Chinese people are unwilling to fall behind. However, in terms of the current development of English in China, there are still great problems especially in the aspect college English listening and speaking teaching. To improve the present conditions of the college English listening and speaking teaching in China, the author puts forward the corresponding improvement strategies, hoping to provide assistance for the Chinese college students' English learning.

Introduction According to the current English levels of primary and secondary school students and even college students in China, the results are unsatisfactory. After more than ten years of English learning, many students still fail to really master this discipline. Taking the spoken English of daily communication for example, the students cannot understand and speak English universally; they are merely good at taking exams and repeating what the book says, yet they are completely unable to communicate with others in daily English. As a leading developing country, China has increased its cultural exchanges and trade cooperation with other countries in recent years. Therefore, China is trying to cultivate a large number of excellent English talents; first of all, rigorous English listening and speaking training should be conducted over college students, so as to enhance the English youth's listening and speaking ability and get prepared for their own and social development.
\end{abstract}

\section{Present Conditions of College English Listening and Speaking Teaching}

\section{Unclear Teaching Objective}

In the current Chinese universities, the students from the excellent 985 and 211 or some ordinary undergraduate colleges are unclear about the teaching objectives developed by teachers while learning English. From the beginning of the semester to the end of the semester, many students do not care about the teaching contents and assignments of teachers, and they merely learn English superficially to complete the assignment. In the English application capability, the college students seldom come into contact with foreign friends, or show English competence in some places. As a result, many students blindly contempt for English listening and speaking teaching, just want to improve their own test results and get a satisfactory transcript. Being affected by the current national conditions, China must implement the examination-oriented education. Although this examination-oriented education has improved the Chinese students' learning motivation to a certain extent, students and teachers have also developed a habit of exam-oriented education, that is, they only value the examination results, lacking the examination over students' practical ability. At the same time, the Chinese college students are actively attending CET4 and CET6 exams, and these English proficiency tests are linked to students' graduation certificates in some universities and colleges. Only by passing the English proficiency tests can students obtain the graduation certificate. To get graduation certificate, the students begin a lot of superficial English learning work to pass the English proficiency tests. English proficiency certificate not only occupies an important position 
in schools, but also plays a key part in the corporate recruitment, which requires the students to present their English proficiency certificates. Due to the pressing demands of schools and employers, students and teachers are learning English in a unified manner, only to pass those English proficiency tests. In the classroom, the teachers impart the vocabulary and grammar required by the English proficiency tests from the beginning to the end, and students may purchase the corresponding exercises for tests after class. Both students and teachers have overlooked the English listening and speaking skills, but blindly pursued to passing tests and achieving excellent written results. Indeed, such a teaching model make most students pass the English proficiency tests, yet the truly mastered and applied aspects fail to meeting the work requirements.

\section{Relatively Backward Teaching Methods and Single Teaching Models}

In the current English teaching, most of the teachers still take the traditional teaching model to teach students. In the teaching, most of the English classes are taught by Chinese to ensure that all students can understand, and the teacher occupies a dominant position. A class is basically dominated by teachers, whereas students have little time to think or actively exchange with others. This teaching method has been adopted for a dozen years, so it is inevitable for the Chinese students to lose interests in learning. In class, most students will silently listen to the teacher, and underline key points occasionally. Besides, basically some distracted students have no idea of the teaching contents. Due to this boring teaching method, the students are not interested in the class. Students can only listen to the teacher to explain and have no opportunity to participate in it, which is not conducive to their mastering of English knowledge.

\section{Large-scale Class Teaching and Outdated Teaching Equipment}

With the social progress, the rapid economic development and the promulgation of expanded enrollment policies, more and more students flock into the campus, yet there are inadequate Chinese college teachers. In many Chinese universities and colleges, the number of teachers and the number of students are in sharp contrast, there are scarce Chinese teachers, especially English major teachers. An English teacher has to teach dozens of students at the same time. Even a small class has forty or fifty students, or even up to sixty or seventy students. This large-scale class teaching mode has seriously hindered the exchange of students and teachers. Because of the large number of students, teachers cannot concern about each student in every aspect. Besides, under such a developed society today, many universities and colleges still use outdated teaching facilities, such as chalks, blackboards and tape recorders. The outdated teaching equipment not only affects the teacher's teaching efficiency, but also diminishes students' interests in learning, causing inefficient transmission of English knowledge from teachers to students.

\section{Lack of A Certain Language Environment and Inadequate Communication with People}

For a language discipline, a free language environment may foster students to master the language more quickly. At present, China is lacking such a convenient environment for students to communicate and exchange. The students could not get practical exercise in class, and their English listening and speaking abilities could not be actually exercised.

\section{Serious Quality of Teachers}

The quality of teachers directly affects the quality of teaching, thereby affecting the students' learning. From the current quality of teachers in Chinese universities and colleges, China has generally weak quality of teachers. Most of them are young teachers just graduated from colleges and universities, they do not fully understand and master the education work, and have insufficient relevant teaching experience. These teachers basically come from different parts of China, having different education backgrounds, seldom studying abroad or talking with foreigners. While the teachers show little confidence in their spoken English, they fail to communicate with students in English.

\section{Improvement Strategies of College English Listening and Speaking Teaching}

China's cultivation of primary and secondary school students and even college students' English competence aims at providing compound talents to the country and the society. In the above text, the present conditions of English listening and speaking teaching in China are analyzed. It is 
obvious to note that the current English teaching in China is confronted with huge problems. Therefore, positive improvement strategies should be made to help students study in a new efficient English class.

\section{Updating Students' Ideas about English and Raising Students' Understanding of English}

At present, China needs to spread the new ideas of English learning to schools, teachers, students and the society, effectively improve the social community, teachers and students' deviation of English listening and speaking teaching, actively change China's wrong view of the exam-oriented education, and put priority to practical English ability. China firstly reforms the above-mentioned English proficiency tests. According to the present conditions of reform of Chinese English proficiency tests in recent years, the listening test has occupied more and more proportion, and the materials of listening tests get more and more close student's daily life. After some reforms and efforts are made by the country and schools, the students should also be aware of their own shortcomings of English learning, whereas the teachers shall actively grasp the English listening and speaking teaching in the future of English learning, and pay more attention to the practical ability of English. After graduation, the students shall not only successfully enter the employer by relying on the English level tests, but also carry out their daily works by their actual English application ability, in order to effectively guarantee that college students output by Chinese universities and colleges may satisfy the needs of today's society and the times.

Actively Improving the Way of College Listening and Speaking Teaching, and Effectively

\section{Enriching the Classroom Form of Students}

An excellent teaching method greatly influences students' acceptance and mastery of this course. In order to make students get interested in English listening and speaking teaching, China should actively adopt the advanced teaching experience in developed countries to ensure that students can actively integrate into the classroom and truly acquire the English knowledge. At the same time, the teachers should also keep the classroom atmosphere active. Under the traditional teaching model, China's classroom teaching atmosphere has been relatively boring, which is not conducive to students' active and effective acquiring of classroom knowledge. Teachers should actively communicate with the students in class, deem the classroom as a communication place, and create an English communication environment for students, so that students get immersed in them, truly acquire the English knowledge, and carry out the fundamental English exchanges.

Speeding up the Construction of Teaching Facilities in China, and Actively Using Modern Educational Technology

In order to effectively improve students' English listening and speaking, China should provide a large amount of teaching funds for colleges and universities, and equip the student classroom with modern teaching facilities. The multimedia classrooms and electronic reading rooms are essential teaching facilities for the modern universities and colleges. These advanced teaching facilities allow teachers and students to remove the limitations of teaching materials and enrich the teaching contents. Teachers may play PPT in the classroom, which may not only effectively saving teachers' time to write on the blackboard, but also effectively strengthen the students' interest in English learning. In order to cultivate students' learning interest, some teachers also download English videos and English songs via multimedia, play in the spare time and encourage students to appreciate.

Creating a Good Language Environment, and Actively Building a Communication and Exchange Platform for Students

In order to create a good language environment for students, the students shall actively use English in classroom or in life, and communicate in English. A good language environment can help students grasp English in a faster and better way. Besides, China should also actively build a communication and exchange platform for students; the colleges and universities should endeavor to provide students with opportunities of studying abroad by taking advantage of available resources, or hire foreign teachers to give English lectures, so that students may feel the charm of English and actively conduct one-on-one communication and exchange with foreign teachers. In addition, the colleges and universities should also organize teachers and students to set up 
English-related associations, English drama performances, or English song contests, strive to cultivate students' interests of learning English, and actively participate in them to feel the joy of English learning.

\section{Actively and Effectively Improving the Overall Quality of English Teachers}

Whether a classroom can make students acquire useful English knowledge is inseparable from a good teacher's teaching work. In order to effectively enhance students' English learning ability, the colleges and universities should strive to improve the overall quality of English teachers, and regularly train the English teachers. In terms of recruitment of English teachers, the colleges and universities should also manage in a rigorous manner and ensure that the quality of English classrooms is guaranteed basically.

\section{Conclusions}

To conform to the development trend of the times, China should actively cultivate compound talents and carry out the teaching by updating students' ideas about English and raising students' understanding of English; actively improving the way of college listening and speaking teaching, and effectively enriching the classroom form of students; speeding up the construction of teaching facilities in china; actively using modern educational technology. While China is in the primary stage of socialism, it is urgent for universities and colleges to continuously transport talents to the society, in order to make contribution to the scientific and technological development in China. At present, there are still many problems in China's college English listening and speaking courses. To handle such problems, the author puts forward the foregoing improvement strategies, hoping to help the Chinese college students' English learning.

\section{References}

[1] Zhang Nan. Present Conditions and Countermeasures of High Vocational English Listening and Speaking Teaching [J]. Journal of Liaoning Teachers College (Social Science Edition), 2015,(02):48-49.

[2] Wang Shuang. Problems and Related Strategies of College English Listening and Speaking Teaching [J]. Journal of Jilin Radio \& TV University, 2011,(07):76-77.

[3] Qi Yanfei. Present Conditions and Improvement Strategy of College English Listening and Speaking Teaching [J]. Heihe Journal, 2010,(03):77-78+87.

[4] Hou Jiaxu. Research on the Reform of Independent College English Listening and Speaking Teaching $[\mathrm{J}]$. Heilongiiang Education (Higher Education Research and Evaluation), 2016,(03):3-4.

[5] Zhou Deyan. Present Conditions, Problems and Countermeasures of College English Listening and Speaking Teaching [J]. Journal of Hainan Normal University (Social Science Edition), 2015,(01):127-131.

[6] Liu Li. Investigation on Present Conditions of College English Listening and Speaking Learning [J]. Journal of Hunan Institute of Engineering (Social Science Edition), 2014,(01):56-60.

[7] Zhang Lei. Research on Improvement Strategies of Vocational English Listening and Speaking Courses [J]. Career Horizon, 2013,(09):76-77+84.

[8] Li Xue. Research on Teaching Reform of College English Listening and Speaking Courses [J]. Education and Vocation,2013,(05):156-157.

[9] Zhu Fengbing. Present Conditions and Improvement Strategies of Vocational English Listening and Speaking Courses [J]. Journal of Zhenjiang College, 2012,(01):85-87.

[10] Guo Yu. Research on Improvement Strategies of Vocational English Listening and Speaking Courses [J]. Journal of Changsha Telecommunications Vocational Technology College, 2011,(04):131-133.

[11] Liu Jingyang. Present Conditions and Teaching Strategies of Vocational English Listening and 
Speaking Teaching [J]. Career, 2010,(35):161-162.

[12] Gong Tanfang. Research on College English Listening and Speaking Learning Behavior [J]. Journal of Yancheng Teachers College (Humanities and Social Sciences Edition), 2010,(03):108-112. 